\title{
Alpine metamorphism of organic matter in metasedimentary rocks from Mt. Medvednica (Croatia)
}

\author{
Katalin Judik ${ }^{1, *}$, Gerd Rantitsch ${ }^{2}$, Thomas M. Rainer ${ }^{2}$, Péter Árkai $^{1} \&$ Bruno Tomljenović $^{3}$
}

Key words: metamorphism, organic matter, vitrinite reflectance, Raman spectroscopy, structural ordering, Internal Dinarides, Mt. Medvednica, Croatia

\begin{abstract}
The diagenetic to low-temperature metamorphic alteration of Mt. Medvednica (Internal Dinarides, Croatia) has been studied by vitrinite reflectance, ordering data of organic matter determined by X-ray powder diffraction and Raman spectroscopy of extracted carbonaceous material.

In metapelites of the Medvednica Metamorphic Complex (MMC), maximum vitrinite reflectance varies between 6.9 and $9.8 \%$. By X-ray powder diffraction, the finely dispersed carbonaceous material is classified as $\mathrm{d}_{1}$-graphite. Based on the "Raman Spectroscopy of Carbonaceous Material Thermometer", peak metamorphic temperatures of ca. $410{ }^{\circ} \mathrm{C}$ are estimated. The degree of organic maturation and the estimated peak temperature correlate fairly well with the Cretaceous (120-80 Ma) high-temperature anchizonal to
\end{abstract}

epizonal metamorphism of the unit, determined by illite Kübler index, chlorite "crystallinity" and K-white mica - chlorite thermobarometry.

In the tectonically higher Jurassic Ophiolitic Mélange and in the unconformably overlying Cretaceous-Paleocene Sequence, random vitrinite reflectance between ca. 0.7 and $2.2 \%$ suggest a stratigraphical trend of the data and therefore a common burial history. In the Jurassic Ophiolitic Mélange and the Cretaceous-Paleocene Sequence, the synmetamorphic carbonaceous material is classified as $\mathrm{d}_{3}$-graphite. In both units, organic thermometers provide peak temperatures of $100-240{ }^{\circ} \mathrm{C}$. These estimates are in accordance with phyllosilicate reaction progress indicators, showing no systematic variation in the stratigraphic succession.

\section{Introduction}

The northern Internal Dinarides comprise pre-Neogene tectonic and sedimentary units formed during different stages in the geodynamic history of the Dinaric branch of the Neotethys and its continental margins. These units are locally exposed as inselbergs (Medvednica, Žumberak, Ivanščica and Kalnik Mts.) within a triangular wedge between the Southalpine Unit, the External Dinarides and the Tisia Unit (Fig. 1). In Mt. Medvednica, following the pre-Eocene structural order from bottom to top (Tomljenović 2002; Tomljenović et al. 2008), these units are (Fig. 2): (1) the very low- to low-grade metamorphic Medvednica Metamorphic Complex (MMC) overlain by (2) the Jurassic Ophiolitic Mélange (or Repno Complex sensu Babić et al. 2002). Both units are unconformably covered by (3) the Cretaceous (Senonian) to Paleocene (Gosau-type) Sequence (Babić et al. 1973; Šikić et al. 1977; Crnjaković 1979, 1987). The Žumberak nappe (4) is thrust upon the Senonian-Paleocene
Sequence at the southwestern edge of Mt. Medvednica (Šikic et al. 1977).

In the Inner Western Carpathians, pre-Neogene tectonic and sedimentary units akin to those of the Internal Dinarides have been described from the Bükk Mts. and its surroundings (e.g. Balogh 1964; Árkai et al. 1995; Csontos 1999, 2000; Pamić et al.2002; Sudar \& Kovács 2006). In terms of petrography, stratigraphy and geochronology of the regional Alpine metamorphic event, the major tectonic units of the Bükk and Medvednica Mts. might have both, a common palaeogeographic origin and a similar pre-Neogene tectonic history. However, in contrast to the comparatively large data base on phyllosilicate "crystallinity" indices, K-Ar and fission track ages of the Bükk area (e.g. Árkai 1983; Árkai et al. 1995 and references therein), a correlative data base on the pre-Neogene units of Mt. Medvednica is published only partly (e.g. Judik 2007; Judik et al. 2004, 2006; Ripsz-Judik 2008; Lugović et al. 2006), and still under construction. Metamorphic temperature and pressure estimates of rock

\footnotetext{
${ }^{1}$ Institute for Geochemical Research, Hungarian Academy of Sciences, H-1112 Budapest, Budaörsi u. 45, Hungary.

${ }^{2}$ Department of Applied Geosciences and Geophysics, University of Leoben, A-8700 Leoben, Peter Tunner Strasse 5, Austria.

${ }^{3}$ Faculty of Mining, Geology \& Petroleum Engineering, University of Zagreb, HR-10000 Zagreb, Pierottijeva 6, Croatia.

*Corresponding author: Katalin Judik. E-mail: judik@geochem.hu
} 
sequences from Mt. Medvednica were described by e.g. Judik et al. (2004) and Lugović et al. (2006).

Carbonaceous matter, often dispersed in siliciclastic and carbonate rocks, is transformed progressively under increasing temperature and pressure conditions. This process can be evaluated quantitatively by vitrinite reflectance measurements (e.g. Teichmüller \& Teichmüller 1981; Taylor et al. 1998), X-ray powder diffraction (Landis 1971) and Raman spectroscopy (Pasteris \& Wopenka 1991; Wopenka \& Pasteris 1993; Yui et al. 1996; Beyssac et al. 2002; Rantitsch et al. 2004, 2005; Rahl et al. 2005). All these methods are used here to better constrain the Cretaceous (Alpine) tectonothermal history of Mt. Medvednica.

Furthermore, phyllosilicate reaction rate indicating parameters (illite Kübler index, chlorite "crystallinity" Árkai index, apparent mean crystallite thickness and lattice strain of illite-K-white mica and chlorite), supplemented by results of empirical chlorite Al(IV) thermometers, the thermobarometer of Vidal \& Parra (2000) and the empirical illite-K-white mica b barometry (see Guidotti \& Sassi 1986) are compared with the obtained organic maturity data.

\section{Geological setting}

In the area north of Zagreb, within the triple junction zone between the Southalpine Unit, the External Dinarides and the Tisia Unit, the overall NW-trend of the Internal Dinarides sharply turns into the ENE direction (Fig. 1). According to Tomljenović et al. (2008) the reason for this dramatic change of trend is a Late Paleogene (possibly Oligocene-earliest Miocene) $130^{\circ}$ clockwise rotation of a tectonic block comprising the Medvednica, Ivanščica and Kalnik Mts. This rotation was caused by right-lateral shear along the Periadriatic-Balaton fault system (e.g. Fodor et al. 1998; Tomljenović et al. 2008) or the Zagorje-Mid-Transdanubian shear zone (Pamić \& Tomljenović 1998), which also resulted in the eastward escape of the Internal Dinaridic units along this fault system, all the way up to the area of the Inner Western Carpathians (e.g. Kázmér \& Kovács 1985; Balla 1989; Haas et al. 2000; Haas \& Kovács 2001; Csontos \& Vörös 2004; Schmid et al. 2008) leading to the recent far displaced positions in the mosaic of the previously neighboring tectonic units.

From bottom to top, the pre-Eocene structural assemblage of Mt. Medvednica comprises the Medvednica Metamorphic Complex, the Jurassic Ophiolitic Mélange, and the Cretaceous-Paleocene Sequence (Tomljenović 2002; Tomljenović et al. 2008; Fig. 2). In the southwestern part of Mt. Medvednica, a thick Triassic platform carbonate succession of the Žumberak Nappe represents the uppermost pre-Neogene structural unit. The Miocene (Ottnangian-Pontian) fill of the Pannonian Basin and Pliocene-Quaternary sequences unconformably overly these units along the southern slopes of the mountain (Šikić et al. 1977; Basch 1995). Along the northwestern foothills, the Upper Miocene strata are frequently overturned and are, together with Pliocene-Quaternary sequences, overthrusted by basement units (Tomljenović \& Csontos 2001).

Cropping out in the central and northeastern part of the range, the lowermost tectonic unit of Mt. Medvednica, the Medvednica Metamorphic Complex (MMC, Šikić et al. 1978; Basch 1983, 1995; Tomljenović 2002) comprises greenschists, metagreywackes, slates, phyllites, marbles, recrystallized dolomites, metaconglomerates and quartzites. Biostratigraphic data prove Silurian to Late Triassic ages of the sediments (Đurđanović 1973; Sremac \& Mihajlović-Pavlović 1983).

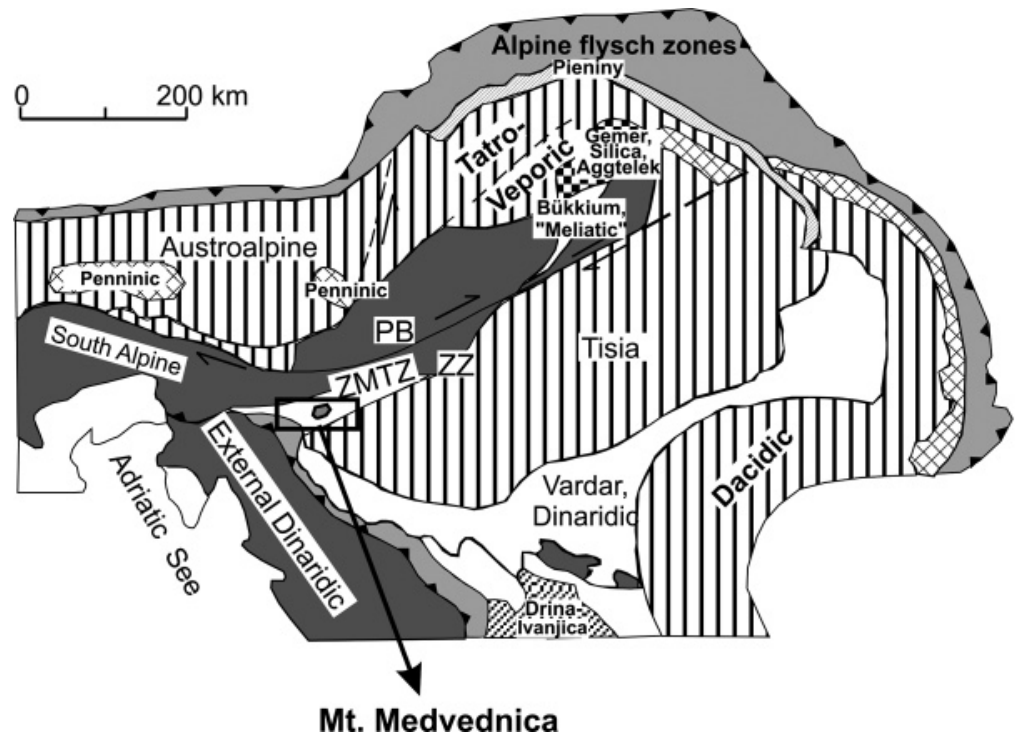

\begin{tabular}{|c|c|}
\hline & $\begin{array}{l}\text { Units related to the Variscan Moldanubian } \\
\text { and Median zones and to the "northern" } \\
\text { (European) Tethys margin }\end{array}$ \\
\hline & $\begin{array}{l}\text { Neotethyan ophiolite complexes } \\
\text { (Vardar, Dinaridic, Bükkium, "Meliatic") }\end{array}$ \\
\hline$x$ & $\begin{array}{l}\text { Penninic - Outer Dacidic ophiolite } \\
\text { complexes }\end{array}$ \\
\hline & Pieniny Klippen Belt \\
\hline & Alpine flysch zones \\
\hline & $\begin{array}{l}\text { Units related to the southern } \\
\text { (Adriatic - Apulian) Tethys margin }\end{array}$ \\
\hline
\end{tabular}

Fig. 1. Simplified tectonic sketch map of the Pannonian Basin and the surrounding areas (after Haas et al. 2000; Kovács et al. 2000); ZMTZ: Zagorje-Mid-Transdanubian Zone, ZZ: Zagreb-Zemplin Lineament, PB: Periadriai-Balaton Line.

606 K. Judik et al. 
Alpine K/Ar whole rock age data obtained on greenschists and on a separated muscovite fraction of a vein vary between 122 and $110 \mathrm{Ma}$ (Belak et al. 1995). The illite-K-white mica rich $<2 \mu \mathrm{m}$ fractions of metasediments show K/Ar ages of $\sim 110 \mathrm{Ma}$. $\mathrm{K} / \mathrm{Ar}$ ages of $\sim 80 \mathrm{Ma}$ were determined in meta-volcanoclastics and meta-igneous rocks (Judik et al.2006). The age differences may be explained by missing inherited, detrital K-white-mica in the metavolcanic-volcanoclastic rocks. The corresponding age data represent minimum ages of the very low- to low-grade metamorphism (Judik et al. 2006). Parameters indicating phyllosilicate reaction rate prove a medium pressure, anchizonal to epizonal regional metamorphism within the MMC (Judik et al. 2004). Based on inorganic empirical thermometers and barometers, the physical conditions of the Alpine metamorphic event were estimated at ca. $300-400^{\circ} \mathrm{C}$ and $3-4$ kbar (Judik et al. 2004; Judik 2007; Lugović et al. 2006).

Thrusted onto the MMC, the diagenetically altered (Judik et al. 2004) Jurassic Ophiolitic Mélange forms a chaotic assemblage of an accretionary wedge (Babić et al. 2002 and references therein). It consists of fragments of metamagmatic rocks, graywackes, radiolarites and limestones, embedded in a sheared shaly-silty matrix (Pamić \& Tomljenović 1998; Babić et al. 2002). Halamić \& Goričan (1995) and Halamić et al. (1999) documented Upper Ladinian to Carnian and Upper Bajocian to Lower Callovian ages of radiolarites, while the age of the shaly-silty matrix was constrained as Lower Jurassic to Bajocian (Babić et al. 2002).

The MMC and the Jurassic Ophiolitic Mélange are both unconformably overlain by the diagenetically altered (Judik et al. 2004) Late Cretaceous-Paleocene (Gosau-type) Sedimentary Sequence comprising alluvial fan and delta fan conglomerates, Inoceramus-bearing sandstones, and Scaglia-type hemipelagic biomicrites and siltstones of Upper Cretaceous age (Šikić et al. 1978; Crnjaković 1979). Locally, biomicrites intercalated with calcareous turbidites and carbonate megabreccias (Babić et al. 1973) grade into calcareous and siliciclastic turbidites of Maastrichtian (Crnjaković 1981) and Paleocene ages (Tomljenović 1995).

Tomljenović et al. (2008) described four pre-Miocene deformational events in Mt. Medvednica (D1-D4). The D1 synmetamorphic deformation is related to Aptian-Albian top-to-thenorth nappe stacking in the central-northern Dinarides, D2 is evidenced by folding and top-to-the-west shearing attributed to Early Albian orogen-perpendicular shortening, D3 folding and thrusting is related to post-Palaeocene, most probably Middle Eocene to Oligocene E-W shortening, and D4 is documented by pervasive dextral shearing on previously formed NE-striking structures. Following the main period of tectonic escape and induced clockwise rotation in the Late Paleogene, Mt. Medvednica and the surrounding inselbergs were affected by Neogene extensional and partly transpressional tectonics, which finally resulted in the formation of basement pop-ups and $\mathrm{km}$-scale folds during Early Miocene to recent times (Tomljenović \& Csontos 2001).
Due to the limited exposures and quite complex structural evolution (Tomljenović \& Csontos 2001; Tomljenović 2002; Tomljenović et al. 2008), the exact origin, formation ages, and even composition of the pre-Neogene units of Mt. Medvednica are still problematic (see e.g. Babić et al. 2002; Slovenec \& Pamić 2002). Hence, the original paleogeographic origin, regional correlation and classification of these units into particular tectonic zones or nappes of the Internal Dinarides further ESE are interpreted controversially (see e.g. Pamić 2002; Schmid et al. 2008 and references therein). In this study we refer to the tectonic subdivision of Schmid et al. (2008) and attribute all mentioned units into the Jadar-Kopaonik thrust sheet of the Internal Dinarides.

\section{Methods}

Organic maturity was determined in selected samples from the MMC (Fig. 2), the Jurassic Ophiolitic Mélange and the Cretaceous-Paleocene Sequence of Mt. Medvednica.

Apparent maximum and minimum vitrinite reflectance $\left(R_{\max }\right.$ and $R_{\text {min }}$ ) in slate and phyllite samples from the MMC and random reflectance $\left(\mathrm{R}_{\mathrm{r}}\right)$ in pelitic and carbonate rock samples from the Jurassic Ophiolitic Mélange and the Late Cretaceous-Paleocene Sequence were measured on polished sections cut perpendicular to the foliation. The measurements were carried out using a LEICA MPV microscope at the University of Leoben, in oil immersion and at a wavelength of $546 \mathrm{~nm} . \mathrm{R}_{\max }$ and $\mathrm{R}_{\min }$ were recorded using polarized light, $\mathrm{R}_{\mathrm{r}}$ were measured in un-polarized light on fine-dispersed vitrinite particles of elongated shape, showing smooth surface and strong bi-reflectance, without evidence of any traces of oxidation and/or re-deposition.

Carbonaceous material (CM) dispersed in pelitic and limestone samples from all the three studied units was characterized also by X-ray powder diffraction (XRPD) of the CM concentrates. The samples were crushed in a jaw crusher, followed by crushing in a mortar mill for $3 \mathrm{~min}$. The organic matter was concentrated by using $\mathrm{HCl}$ and $\mathrm{HF}$. An amount of $1-3 \mathrm{mg} / \mathrm{cm}^{2}$ of the organic concentrates was mounted onto glass slides and dried at room temperature. Diffraction patterns were obtained by a Philips PW-1730 diffractometer (with computerized APD system) at the Institute for Geochemical Research (Hungarian Academy of Sciences) using the following instrumental and measuring conditions: $\mathrm{CuK}_{\alpha}$ radiation, $45 \mathrm{kV}, 35 \mathrm{~mA}$, proportional counter, graphite monochromator and divergence and detector slits of $1^{\circ}$. Data were collected with 0.01 and $0.02^{\circ} 2 \Theta$ steps, applying time intervals of $1 \mathrm{~s}$ and $5 \mathrm{~s}$, respectively. The peak position of the 002 reflection of the $\mathrm{CM}$ was determined according to Landis (1971).

Raman spectra of the dispersed CM were obtained on the organic concentrates of selected samples from all three units. For the acquisition of the Raman spectra, a Dilor confocal Raman spectrometer equipped with a frequency-doubled Nd-YAG laser $(100 \mathrm{~mW}, 532.2 \mathrm{~nm})$ and diffraction gratings of 1200 and 1800 grooves/mm, a Peltier-cooled, slow-scan, CCD 


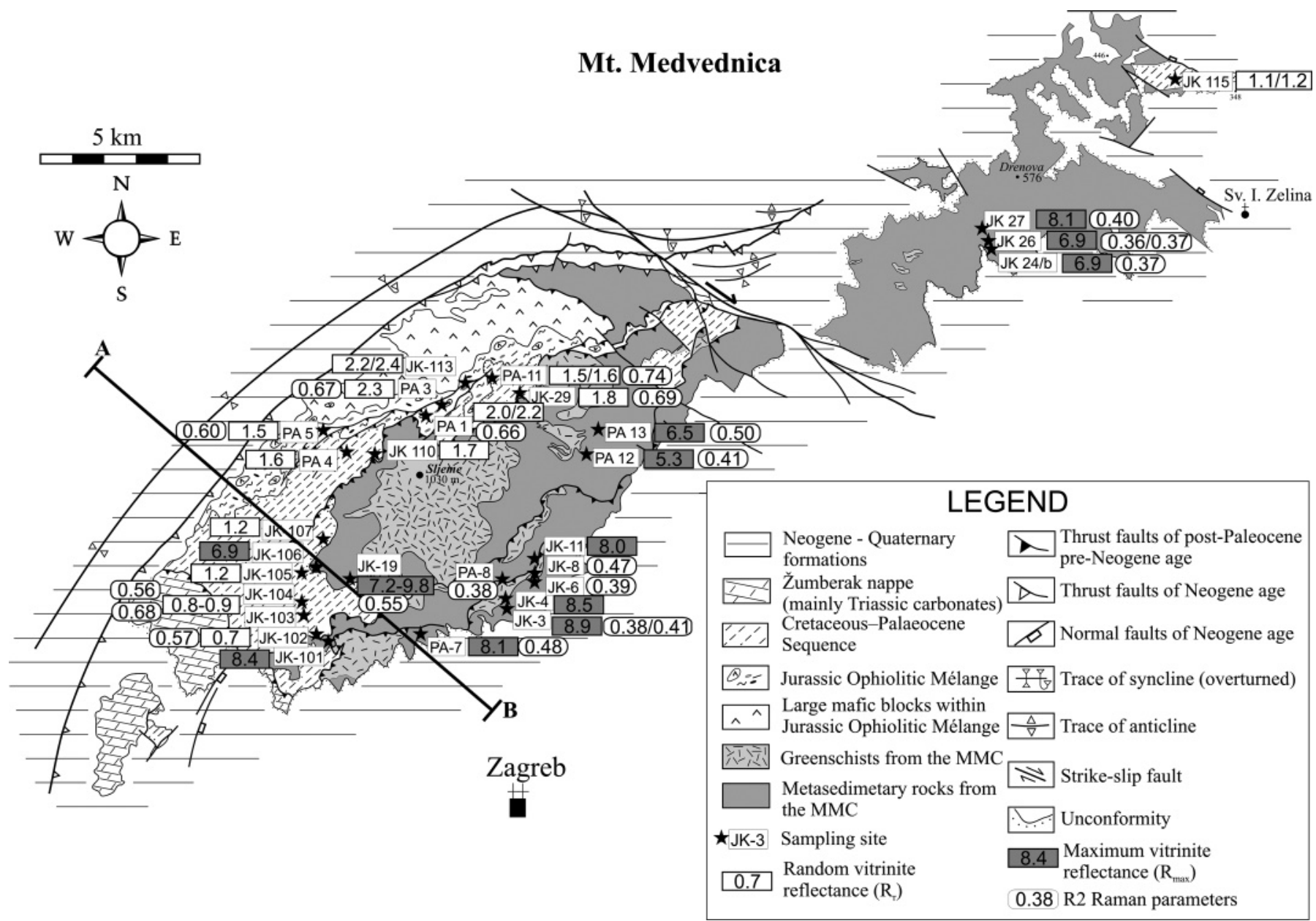

Fig. 2. Geological map showing the study area with the sample locations (modified after Šikić et al. 1978 and Tomljenović 2002) and the measured vitrinite reflectance and R2 ratios in Mt. Medvednica. MMC: Medvednica Metamorphic Complex.

matrix-detector and an Olympus BX 40 microscope were used at the University of Leoben. To obtain a better signal to noise ratio five scans with an acquisition time of $30 \mathrm{sec}$ in the $700-2000 \mathrm{~cm}^{-1}$ (first-order) and $2200-3200 \mathrm{~cm}^{-1}$ (secondorder) region are summed. Five spectra were recorded for each sample. The measured first-order bands of the Raman spectra were the D1 (Beyssac et al. 2002) or D band (Yui et al. 1996) at $\sim 1350 \mathrm{~cm}^{-1}$; the $\mathrm{G}$ (Beyssac et al. 2002) or O band (Yui et al. 1996) at ca. $1580 \mathrm{~cm}^{-1}$, the $\mathrm{D} 2$ band at $\sim 1610 \mathrm{~cm}^{-1}$, and the D3 band at $\sim 1500 \mathrm{~cm}^{-1}$. The second-order bands were recorded at $\sim 2450 \mathrm{~cm}^{-1}, \sim 2700 \mathrm{~cm}^{-1}$ (S1 band) and $\sim 2900 \mathrm{~cm}^{-1}$ (S2 band, Beyssac et al. 2002). Peak position, area and peak width (full width at half maximum-FWHM) of the bands were determined using the computer program LAB-SPEC 2.08 (Dilor SA). The $\mathrm{R} 1$ ratio is calculated as $D 1 / G$ peak intensity ratio and the $\mathrm{R} 2$ ratio is given as $D 1 /(G+D 1+D 2)$ peak area ratio (Beyssac et al. 2002).

\section{Results}

\section{Organic petrography}

Slates and phyllites from the MMC contain highly bireflecting, elongated vitrinite particles with an average length of $2-10 \mu \mathrm{m}$, oriented mainly parallel to the foliation. In many cases the width of these particles is smaller than the spot diameter of the microscope, thus in some slate samples only a few particles provided acceptable conditions for vitrinite reflectance measurements. In general, vitrinite particles in the MMC are characterized by smooth surfaces, but some grains show granular, mosaic-like structure.

Siliciclastic and carbonate rocks samples from the Jurassic Ophiolitic Mélange and the Cretaceous-Paleocene sequence contain vitrinite particles with visible bireflectance and smooth surfaces. In addition to vitrinite grains, in lower amounts, inertinite particles with sharp boundaries, higher reflectance and with no optical anisotropy are recognized in the samples.

608 K. Judik et al. 
Table 1. (a) $\mathrm{R}_{\max }$ and $\mathrm{R}_{\min }$ data from metapelites of the MMC.

\begin{tabular}{|c|c|c|c|c|c|c|c|c|}
\hline Sample & Lithotype & $\begin{array}{l}\mathbf{R}_{\max } \\
(\%)\end{array}$ & $\mathbf{s}$ & $\begin{array}{l}\mathbf{R}_{\min } \\
(\%)\end{array}$ & $\mathbf{s}$ & Bireflection & $\mathbf{n}$ & $\begin{array}{l}\text { Biostratigraphic } \\
\text { protolith age }\end{array}$ \\
\hline \multicolumn{9}{|c|}{ Medvednica Metamorphic Complex } \\
\hline JK-3 & slate & 8.86 & 2.27 & 1.81 & 0.34 & 7.05 & 6 & Devonian \\
\hline JK-4 & $\begin{array}{l}\text { marble with phyllite } \\
\text { intercalations }\end{array}$ & 8.51 & - & 1.14 & - & 7.37 & 2 & Devonian \\
\hline JK-11 & phyllite & 7.96 & 0.99 & 1.31 & 0.28 & 6.65 & 10 & Anisian or Carboniferous \\
\hline $\mathbf{J K}-19 / \mathbf{a}$ & slate & 7.71 & 0.57 & 1.56 & 0.46 & 6.15 & 30 & Middle-Late Triassic (?) \\
\hline JK-19/b & phyllite & 9.76 & 1.63 & 1.91 & 0.51 & 7.85 & 21 & Middle-Late Triassic (?) \\
\hline JK-19/3 & phyllite & 7.22 & 0.69 & 1.94 & 0.42 & 5.28 & 30 & Middle-Late Triassic (?) \\
\hline JK-24b/1 & phyllite & 6.94 & 0.48 & 1.26 & 0.20 & 5.68 & 40 & Paleozoic (?) \\
\hline JK-26 & phyllite & 6.88 & 0.64 & 2.07 & 0.31 & 4.81 & 4 & Paleozoic (?) \\
\hline JK-27 & metasandstone & 8.13 & 0.63 & 2.33 & 0.42 & 5.80 & 19 & Paleozoic (?) \\
\hline JK-101 & phyllite & 8.44 & 0.66 & 2.30 & 0.34 & 6.14 & 10 & Middle-Late Triassic \\
\hline JK-106/1 & phyllite & 6.92 & 1.09 & 1.43 & 0.27 & 5.49 & 30 & Triassic (?) \\
\hline PA-7 & phyllite & 8.14 & 0.64 & 1.60 & 0.11 & 6.54 & 3 & Late Triassic \\
\hline PA-12 & phyllite & 6.50 & 0.36 & 2.62 & 0.47 & 3.88 & 9 & Middle-Late Triassic \\
\hline PA-13 & slate & 5.28 & 0.23 & 2.07 & 0.28 & 3.21 & 7 & Middle-Late Triassic \\
\hline
\end{tabular}

$\mathrm{n}$ : number of measurements, $\mathrm{R}_{\max }$ : maximum vitrinite reflectance, $\mathrm{R}_{\min }$ : minimum vitrinite reflectance, $\mathrm{s}$ : standard deviation.

\section{Vitrinite reflectance}

In the MMC, maximum reflectance values vary between $6.9 \%$ and $9.8 \%$, minimum reflectance data range between 1.3 and $2.3 \%$ (Table 1 ). No systematical spatial variation of the data can be recognized (Fig. 2).

Average values of $2.20 \%$ and $1.27 \% \mathrm{R}_{\mathrm{r}}$ were measured on siliciclastic and carbonate rocks from the Jurassic Ophiolitic Mélange and the Cretaceous-Paleocene Sequence (Table 2).

\section{$X R P D$ characterization of the dispersed $C M$}

In the MMC, $d$ values of $3.35-3.36 \AA$ (Table 3 ) indicate the graphite- $\mathrm{d}_{1}$ stage of Landis (1971). Landis (1971) correlated the graphite- $\mathrm{d}_{1}$ stage with the pumpellyite-actinolite facies and the chlorite zone of the greenschist facies.

In some XRPD patterns from concentrates of the Jurassic Ophiolitic Mélange and the Cretaceous-Paleocene Sequence, sharp and intense peaks at ca. 3.35-3.36 ̊̊ superimpose broad, low intensity $\mathrm{d}_{3}$-graphite peaks at ca. $3.50 \AA$. The broad peaks are features of synmetamorphic $\mathrm{CM}$, whereas the graphite- $\mathrm{d}_{1}$ peaks are related to an older, detrital, high-ranked CM population (Fig. 3). Landis (1971) correlated the $\mathrm{d}_{3}$-graphite with the zeolite facies and the prehnite-pumpellyite facies.

\section{Raman spectroscopy}

Raman spectra acquired from slate and phyllite samples of the MMC display sharp and intense G peaks at $\sim 1578 \mathrm{~cm}^{-1}$, D1

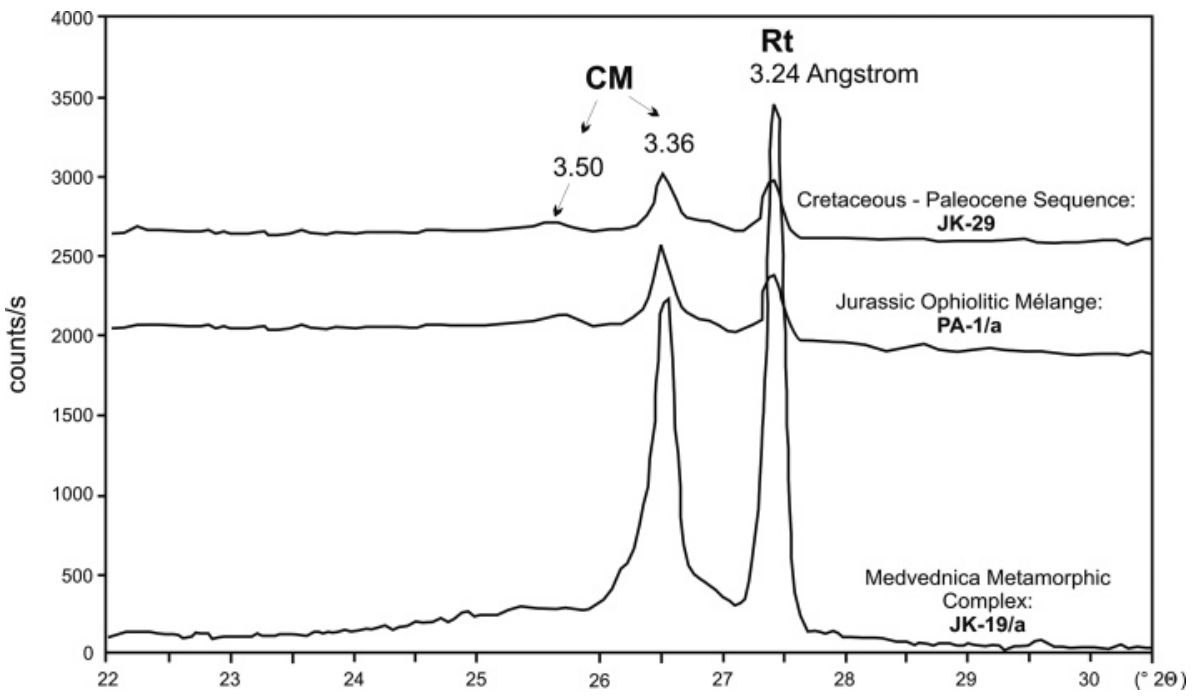

Fig. 3. Representative XRPD patterns from the studied units of Mt. Medvednica, CM: extracted carbonaceous matter, Rt: rutile. 
Table 2. $\mathrm{R}_{\mathrm{r}}$ and calculated maximum temperatures (Barker 1988 equation) of siliciclastic and carbonate rocks from the Jurassic Ophiolitic Mélange and the Cretaceous-Paleocene Sequence of Mt. Medvednica.

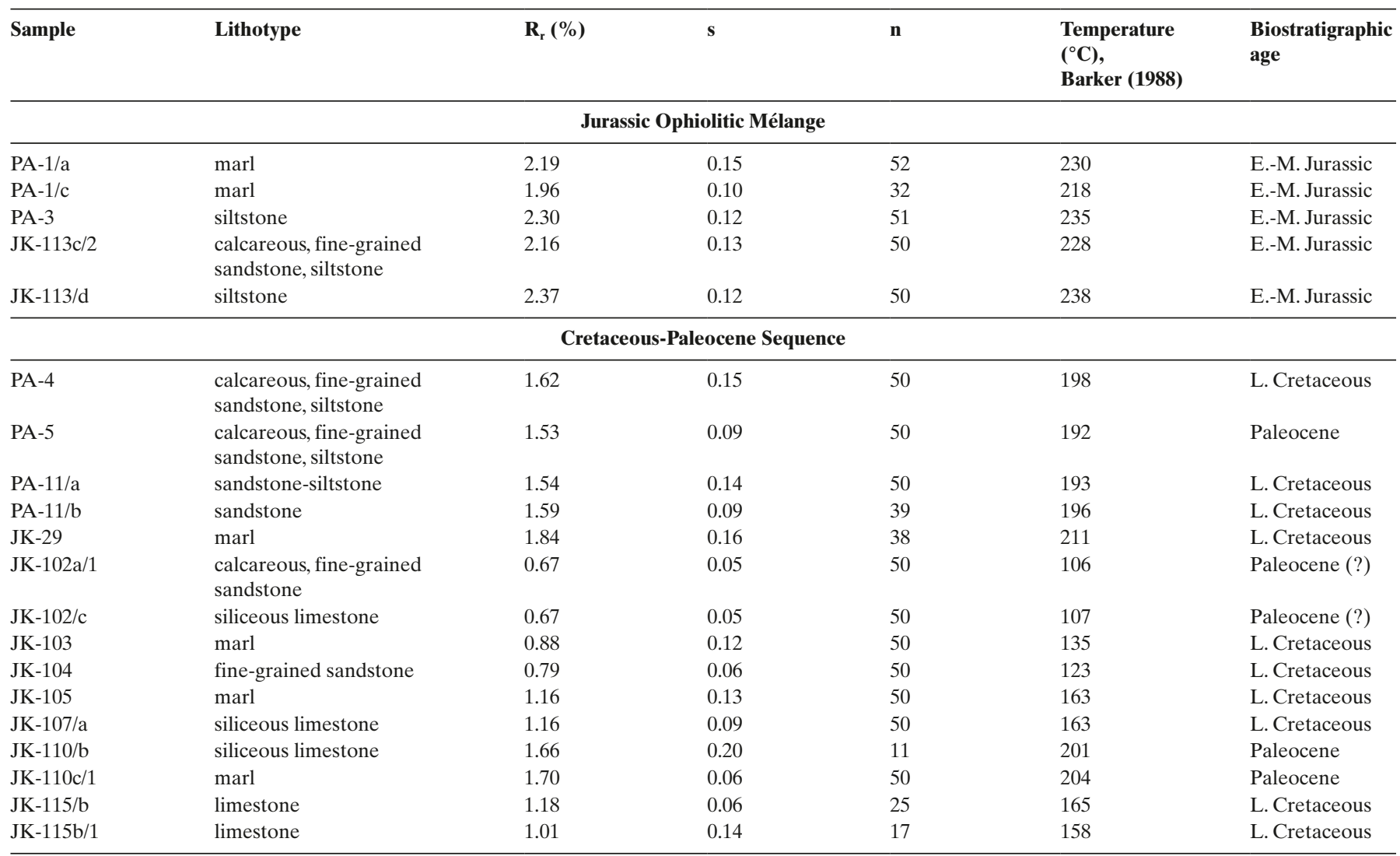

$\mathrm{n}$ : number of measurements, $\mathrm{R}_{\mathrm{r}}$ : random vitrinite reflectance, s: standard deviation.

peaks at $\sim 1347 \mathrm{~cm}^{-1}$, and weakly resolved, broad shoulders of the D1 bands at $\sim 1615 \mathrm{~cm}^{-1}$ indicating the D2 peak (Fig. 4). The second-order spectra are characterized by bands at $\sim 2446 \mathrm{~cm}^{-1}$, $2693 \mathrm{~cm}^{-1}$ and $2951 \mathrm{~cm}^{-1}$ (Table 4).

D1 bands at $\sim 1352 \mathrm{~cm}^{-1}$ and $\mathrm{G}$ peaks at ca. $1602 \mathrm{~cm}^{-1}$ were measured on the first-order Raman spectra of samples from the Jurassic Ophiolitic Mélange. No spatial variation in the data can be recognized (Fig. 2).

The Raman spectra of some samples from the CretaceousPaleocene Sequence indicate the contribution of detrital CM (Table 4 and Fig. 4).

\section{Discussion}

\section{Paleotemperature estimations}

It is well documented that Raman spectra of fine-dispersed CM change systematically with increasing metamorphic grade (Pasteris \& Wopenka 1991; Wopenka \& Pasteris 1993; Yui et al. 1996; Beyssac et al. 2002; Rantitsch et al. 2004, 2005; Rahl et al. 2005). Beyssac et al. (2002) investigated CM particles in situ beneath transparent grains in sections orientated perpendicular to the foliation. They described an empirical equation
(1) in which the peak metamorphic temperature $\left(\mathrm{T}_{\max }\right)$ was calculated as a linear function of the R2. The thermometer is calibrated in the range of $330-650{ }^{\circ} \mathrm{C}$.

Table 3. Results of the XRPD characterization of the dispersed carbonaceous material concentrated from selected rock samples from Mt. Medvednica.

\begin{tabular}{|c|c|c|c|}
\hline Sample & Lithotype & $\begin{array}{l}\text { d(002) } \\
(\AA)\end{array}$ & $\begin{array}{l}\text { graphite } \\
\text { "ordering"** }\end{array}$ \\
\hline \multicolumn{4}{|c|}{ Medvednica Metamorphic Complex } \\
\hline JK-3_1 & slate & 3.36 & graphite- $\mathrm{d}_{1}$ \\
\hline JK-3_2 & slate & 3.35 & graphite- $\mathrm{d}_{1}$ \\
\hline JK-19 & slate & 3.36 & graphite- $\mathrm{d}_{1}$ \\
\hline JK-26_1 & phyllite & 3.36 & graphite- $\mathrm{d}_{1}$ \\
\hline JK-26_2 & phyllite & 3.36 & graphite- $\mathrm{d}_{1}$ \\
\hline \multicolumn{4}{|c|}{ Jurassic Ophiolitic Mélange } \\
\hline PA-1/a & marl & $\sim 3.50$ & graphite- $\mathrm{d}_{3}$ \\
\hline \multicolumn{4}{|c|}{ Cretaceous-Paleocene Sequence } \\
\hline JK-29 & marl & $\sim 3.50$ & graphite- $\mathrm{d}_{3}$ \\
\hline
\end{tabular}

* after Landis (1971). 


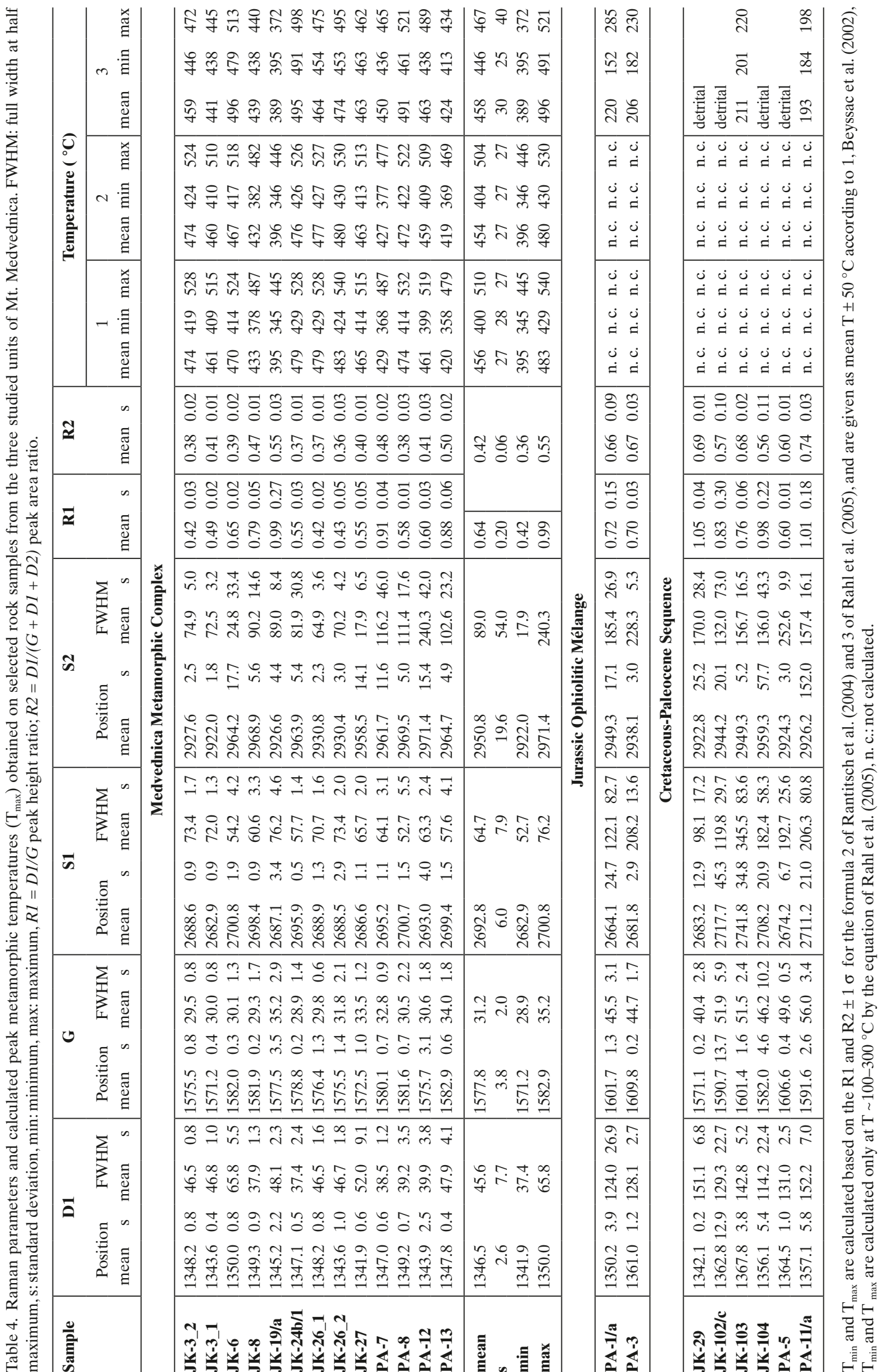



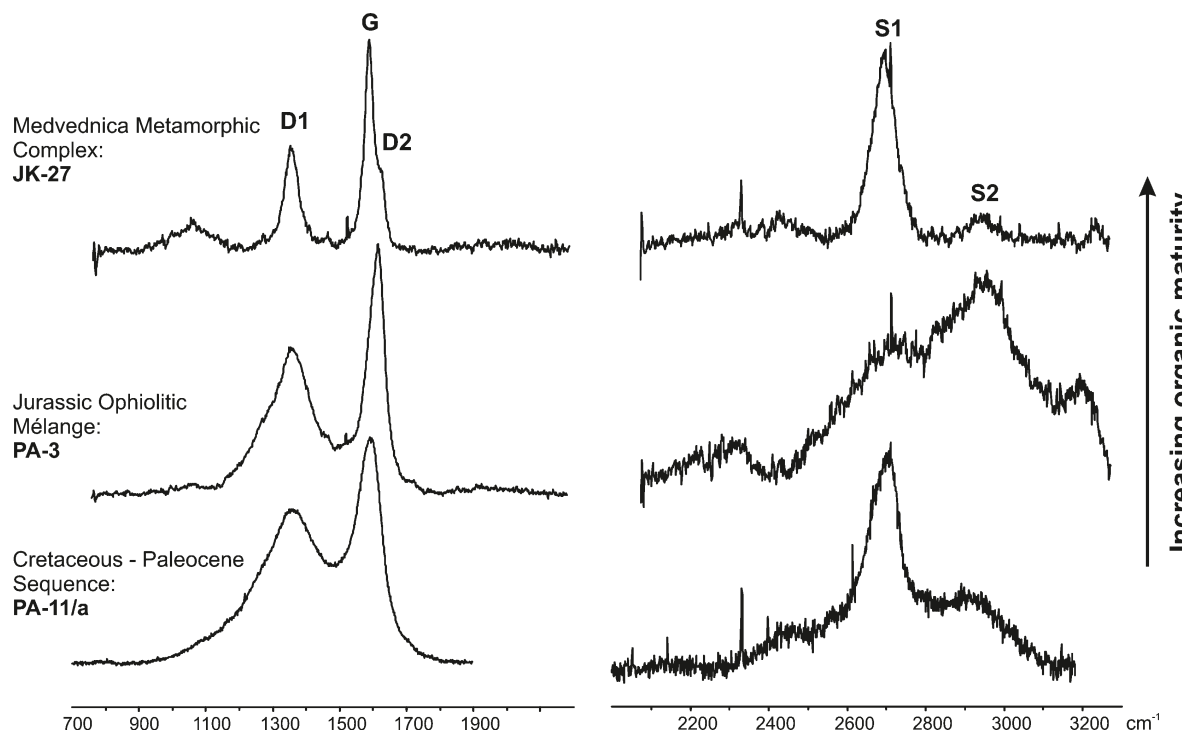

Fig. 4. Representative first- and corresponding second-order Raman spectra from Mt. Medvednica. Note the well-ordered second order spectrum in sample PA-11/a indicating a detrital component in the $\mathrm{CM}$.
$T\left({ }^{\circ} \mathrm{C}\right)=-445 R 2+641$

Rantitsch et al. (2004) modified the equation of Beyssac et al. (2002) and applied equation (2) successfully for dispersed organic material separated from acid-treated whole rock samples.

$T\left({ }^{\circ} \mathrm{C}\right)=-(457 \pm 53) R 2+648 \pm 25$

Rahl et al. (2005) gave peak metamorphic temperature estimates (3) of in situ CM using the degree of resetting of lowtemperature thermochronological data (apatite and zircon fission track ages, (U-Th)/He ages) at temperatures as low as $100{ }^{\circ} \mathrm{C}$.

$T\left({ }^{\circ} \mathrm{C}\right)=737.3+320.9 R 1-1067 R 2-80.638 R 1^{2}$

By applying these formulae, a $\mathrm{T}_{\max }$ of $460 \pm 50{ }^{\circ} \mathrm{C}$ is obtained for the MMC (Table 4). However, depending on their whole rock chemical composition, pelitic rocks affected by thermal alteration of ca. $450{ }^{\circ} \mathrm{C}$ may contain biotite and/or garnet as metamorphic facies indicating minerals (see e.g. Bucher \& Frey 1994). They are absent in the studied slate and phyllite samples from the MMC (Judik et al. 2004; Judik 2007). Therefore, minimum calculated $\mathrm{T}_{\max }$ of ca. $410{ }^{\circ} \mathrm{C}$ is used for further interpretation for the MMC (Table 4).

Using equation (3), peak metamorphic temperatures of 190 to $220^{\circ} \mathrm{C}$ are estimated from representative samples of the Jurassic Ophiolitic Mélange and the Cretaceous-Paleocene Sequence.

As an alternative, maximum alteration temperatures of the Jurassic Ophiolitic Mélange and the Cretaceous-Paleocene Sequence can be quantified from vitrinite reflectance data using the empirical equation of Barker (1988). This approach consid- ers the temperature as prime factor that controls the maturation of the CM, excluding the effect of a short, intense heat pulse. Based on the above-mentioned facts and noticing that the burial history and the physical properties of preserved and eroded sedimentary rocks of the units are not well established, a temperature of $230 \pm 8{ }^{\circ} \mathrm{C}$ is given by the method of Barker (1988) for samples from the Jurassic Ophiolitic Mélange. In the Cretaceous-Paleocene Sequence temperatures vary between 100 and $210{ }^{\circ} \mathrm{C}$. These estimates are consistent with the "Raman temperatures".

\section{Thermal history}

The present data coverage indicates a hiatus in organic maturity data between the MMC and the overlying units (Fig. 5). In the MMC vitrinite reflectance of ca. $7.8 \% \mathrm{R}_{\max }$ is correlated to the graphite- $\mathrm{d}_{1}$ stage of Landis (1971). The graphite $\mathrm{d}_{1}$-stage in turn correlates to the pumpellyite-actinolite facies and chlorite zone of the greenschist facies (Landis 1971). Raman spectroscopy suggests peak paleotemperatures of ca. $410{ }^{\circ} \mathrm{C}$. The MMC suffered Cretaceous metamorphism at 120-80 Ma (Belak et al. 1995; Judik et al. 2006). To explain this thermal alteration by burial heating, we have to assume an eroded succession of a 10-12 km thick pre-Cretaceous rock sequence on top of it. However, there is no evidence for such an overburden (Šikić 1995). Consequently, metamorphism of organic matter in the MMC can not be explained by sedimentary burial. Therefore, we speculate about a tectonic burial of the MMC beneath cover nappe(s) that are not preserved in $\mathrm{Mt}$. Medvednica. Missing evidence prevents a more conclusive interpretation.

The overlying Jurassic Ophiolitic Mélange and the Cretaceous-Paleocene Sequence were affected by a significantly lower thermal alteration. In these sequences, synmetamorphic 


\section{PROFILE A - B}

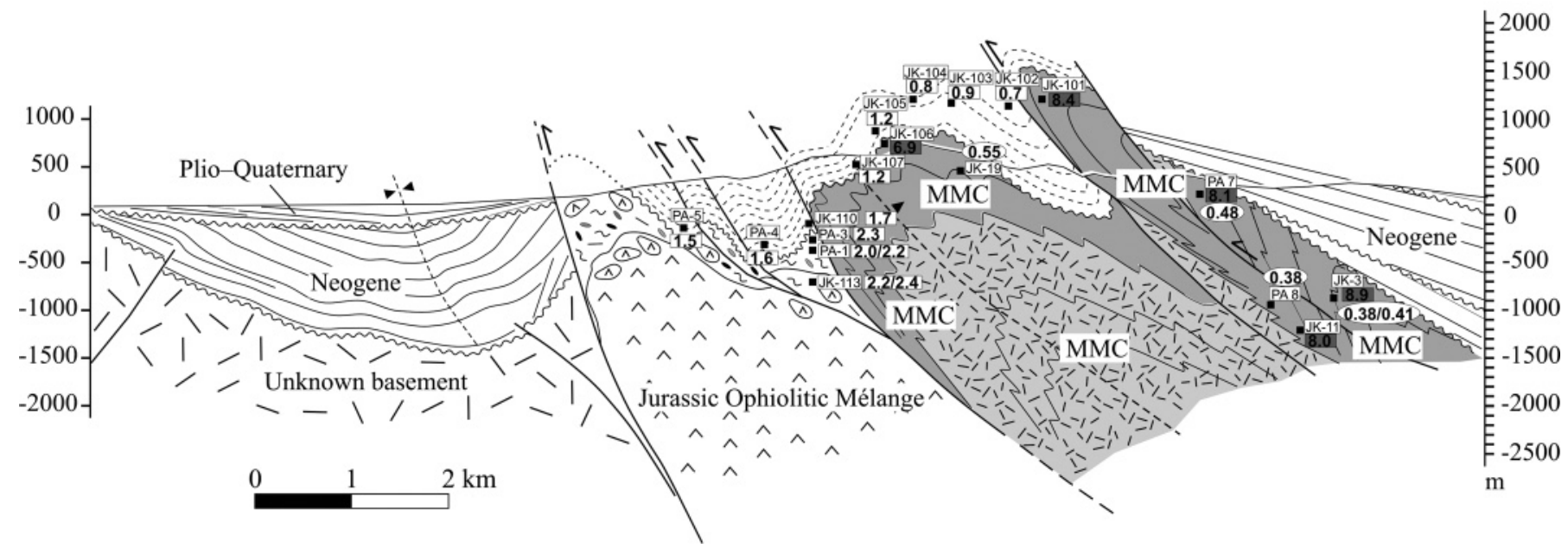

Fig. 5. Geological cross section of Mt. Medvednica (modified after Tomljenović et al. 2008 and Tomljenović 2002) with $R_{r}, R_{\max }$ (in grey) and R2 parameters (encircled). For legend, see Fig. 2.

$\mathrm{d}_{3}$-graphite can be correlated with the zeolite facies and the prehnite-pumpellyite facies. Vitrinite reflectance within the Cretaceous-Paleocene Sequence is only slightly lower than the data obtained from the Jurassic Ophiolitic Mélange complex. This might suggest a heating of the succession during burial of the Cretaceous (Jurassic?) to Paleocene strata. The vitrinite reflectance pattern (Fig. 2) suggests a thermal peak before or during post-Paleocene to pre-Early Miocene D3 folding of the sequence (Tomljenović et al. 2008).

\section{Organic maturity versus phyllosilicate characteristics}

A reasonably consistent correlation between inorganic (e.g. phyllosilicate characteristics) and organic indicators was established from a large number of data, accumulated during the last 40 years (see e.g. Kisch 1987; Merriman \& Peacor 1999; Árkai et al. 2007). In this period, numerous papers described the chemi$\mathrm{cal}$, mineralogical, lithological and kinetic controls of organic maturation and phyllosilicate reactions. It is generally accepted that temperature is the main physical factor influencing both indicators (see Frey 1987). However, differences in the rates of phyllosilicate reactions in relation to organic maturation and the presence of numerous driving forces for the contributing processes prevent the establishment of a global, overall valid correlation. On the other hand, correlation can give valuable information about heat flow processes in upper crustal levels. Therefore, a local correlation between phyllosilicate reaction rate indicating parameters (illite Kübler index, chlorite "crystallinity" Árkai index, apparent mean crystallite thickness and lattice strain of illite-K-white mica and chlorite, and results of empirical chlorite $\mathrm{Al}(\mathrm{IV})$ thermometers and those of the thermobarometer of Vidal \& Parra 2000) and organic maturity data (vitrinite reflectance, XRPD-based graphite-d stage and Raman parameters) is given here.

The MMC was affected by high-temperature anchizonal to epizonal regional metamorphism (Judik et al. 2004) determined by illite "crystallinity" Kübler index values of 0.22 $0.31 \Delta^{\circ} 2 \Theta$ (Fig. 6), chlorite "crystallinity" (Árkai index) data of $0.24-0.43 \Delta^{\circ} 2 \Theta$, apparent mean crystallite thickness $(D)$ of ca. $486 \pm 78 \AA$ for ca. 10 A illite-K-white mica basal reflections and ca. $505 \pm 158 \AA$ for chlorite reflections at ca. $7 \AA$. The empirical chlorite Al(IV) thermometers (Cathelineau 1988; Kranidiotis \& MacLean 1987; Jowett 1991) and thermobarometer of Vidal \& Parra (2000) estimated ca. $270-410{ }^{\circ} \mathrm{C}$ and $3.5-4$ kbar. The Kübler index zones correlate fairly well with $\mathrm{R}_{\max }$ of $6.9-9.8 \%$ (Fig. 6), the graphite- $\mathrm{d}_{1}$ stage of organic maturation (see Árkai et al. 2007; Merriman \& Kemp 1996), and Raman peak paleotemperatures of ca. $410^{\circ} \mathrm{C}$.

The Jurassic Ophiolitic Mélange and the Cretaceous-Paleocene Sequence suffered diagenetic (partly low-temperature anchimetamorphic) alteration. Illite Kübler index values are $0.35-0.60 \Delta^{\circ} 2 \Theta$ and $0.37-0.78 \Delta^{\circ} 2 \Theta$ (Fig. 6) and the chlorite Árkai index data vary between $0.29-0.67 \Delta^{\circ} 2 \Theta$ and $0.32-0.54$ $\Delta^{\circ} 2 \Theta$ for the Jurassic Ophiolitic Mélange and the CretaceousPaleocene Sequence, respectively. The mean crystallite thicknesses of illite-K-white mica and chlorite in the Jurassic Ophiolitic Mélange are $184 \pm 39 \AA$ and $264 \pm 88 \AA$, respectively. $D$ values of ca. $197 \pm 50 \AA$ and $297 \pm 41 \AA$ are determined from the Cretaceous-Paleocene Sequence. Temperatures of ca. $230{ }^{\circ} \mathrm{C}$ are estimated from vitrinite reflectance data in the Jurassic Ophiolitic Mélange. Slightly lower temperatures of ca. $100-210{ }^{\circ} \mathrm{C}$ derive from vitrinite reflectance values in the Cre- 


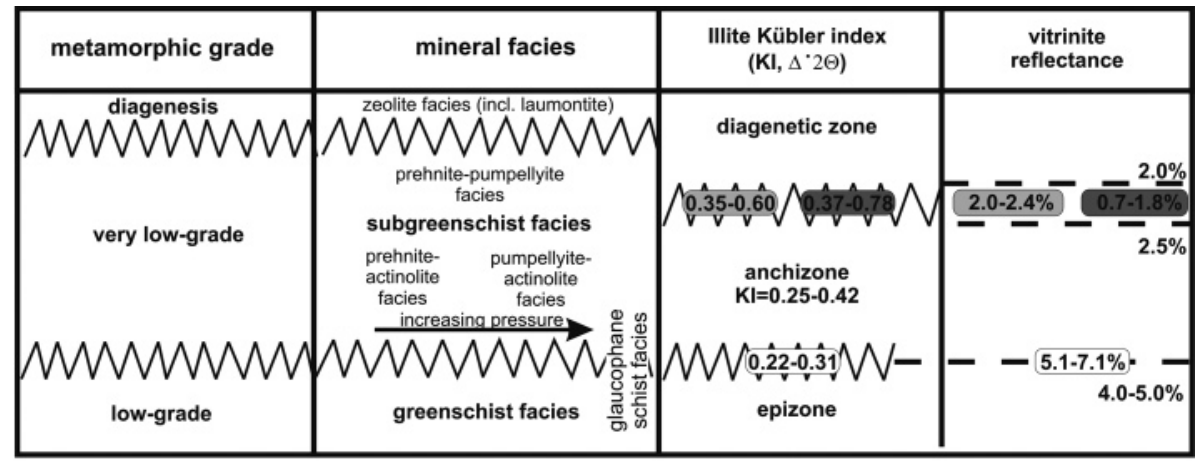

Fig. 6. Correlation of organic maturity and phyllosilicate reaction rate indicating parameters (Judik et al. 2004) from Mt. Medvednica.

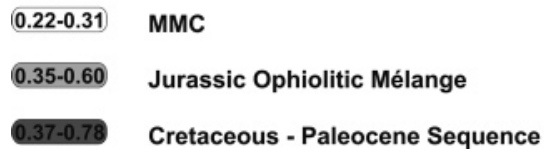

taceous-Paleocene sequence. Although the calibration of the Raman thermometer was extended into the diagenetic zone, the presence of detrital, "ordered" CM ( $\mathrm{d}_{1}$-graphite) in addition to the synmetamorphic CM ( $\mathrm{d}_{3}$-graphite) limits the application of the temperature calibration of Rahl et al. (2005) in $\mathrm{CM}$ concentrates of diagenetically altered rocks of Mt. Medvednica. Raman spectra of samples containing pure synmetamorphic CM give peak temperatures which are in agreement with temperature estimates obtained by using the formular of Barker (1988).

\section{Summary}

In this study, the diagenetic-low-temperature metamorphic alteration of Mt. Medvednica (Croatia) of the Internal Dinarides (Schmid et al. 2008) has been characterized by vitrinite reflectance of dispersed carbonaceous material, X-ray powder diffraction and Raman spectroscopy of extracted carbonaceous material.

Vitrinite reflectance in the Medvednica Metamorphic Complex (MMC) ranges between 6.9 to $9.8 \% \mathrm{R}_{\max }$. The finedispersed organic material is classified as $\mathrm{d}_{1}$-graphite of Landis (1971). The organic maturity stages are correlated with the pumpellyite-actinolite facies and to the chlorite zone of the greenschist facies as well as with the high-temperature anchizone to epizone. A peak metamorphic temperature of ca. $410{ }^{\circ} \mathrm{C}$ is estimated from the "Raman Spectroscopy of Carbonaceous Material Thermometer". The MMC suffered metamorphism during the Cretaceous at ca. 120-80 Ma (Judik et al. 2006; Belak et al. 1995). Metamorphism of the organic matter within this unit cannot be explained by sedimentary burial.

In samples from the Jurassic Ophiolitic Mélange and the Cretaceous-Paleocene Sequence, the vitrinite reflectance values are ca. $2.20 \%$ and $1.27 \% \mathrm{R}_{\mathrm{r}}$. Varying organic maturity data in the units contrast with very similar diagenetic (partly low-temperature anchimetamorphic) phyllosilicate reaction progress indicat- ing parameters (Judik et al. 2004). In the Cretaceous-Paleocene Sequence, vitrinite reflectance nearly matches data from the Jurassic Ophiolitic Mélange complex. This observation might suggest their common burial and thermal history.

\section{Acknowledgements}

This paper presents new results of a scientific co-operation project led by Jakob Pamić and Péter Árkai within the frame of a bilateral agreement between the Croatian Academy of Sciences and Arts and the Hungarian Academy of Sciences, and an Austrian Exchange Service project. The authors are grateful to R.F. Sachsenhofer, D. Balen, D. Tibljaš and K. Balogh for numerous discussions. F. Nieto and R. Sassi are thanked for their thorough reviews and constructive suggestions. Thanks are due to M. Tóth, P.M. Sándor, O. Komoróczy, K. Temesvári, N. Szász for their technical assistance. The authors are indebted to the Hungarian National Research Fund (OTKA, Budapest), project No. T-049454 to P. Árkai., No. M-41434 to K. Balogh and to the Ministry of Science, Education and Sports of the Republic of Croatia, projects No. 0119412 and 195-1951293-3155 for financial support.

\section{REFERENCES}

Árkai, P. 1983: Very low- and low-grade Alpine regional metamorphism of the Paleozoic and Mesozoic formations of the Bükkium, NE-Hungary. Acta Geologica Hungarica 26, 83-101.

Árkai, P., Balogh, K. \& Dunkl, I. 1995: Timing of the low-temperature metamorphism and cooling of the Paleozoic and Mesozoic formations of the Bükkium, innermost Western Carpathians, Hungary. Geologische Rundschau 84, 334-344.

Árkai, P., Sassi, F.P. \& Desmons, J. 2007: Very low- to low-grade metamorphic rocks. In: Fettes, D. \& Desmons, J. (Eds.): Metamorphic Rocks: A Classification and Glossary of Terms: Recommendations of the International Union of Geological Sciences Subcommission on the Systematics of Metamorphic Rocks. Cambridge University Press, Cambridge, UK, 36-42.

Babić, L.J., Gušić, I. \& Nedela-Devide D. 1973: Senonian breccias and overlying deposits on Mt. Medvednica (Northern Croatia) (in Croatian). Geološki vjesnik 25, 11-27.

Babić, L.J., Hochuli, P.A. \& Zupanić J. 2002: The Jurassic ophiolitic mélange in the NE Dinarides: Dating, internal structure and geotectonic implications. Eclogae Geologicae Helvetiae 95, 263-275.

Balla, Z. 1989: On the origin of the structural pattern of Hungary. Acta Geologica Hungarica, 31, 53-63. 
Balogh, K. 1964: Die geologischen Bildungen des Bükk-Gebirges. Annales of the Geological Institute of Hungary 48, 245-719.

Barker, C. E. 1988: Geothermics of petroleum systems: Implications of the stabilization of kerogen maturation after a geologically brief heating duration at peak temperature. In: Magoon, L.B. (Ed.): Petroleum Systems of the United States. U. S. Geological Survey Bulletin 1870, 26-29.

Basch, O. 1983: Geological map M 1:100.000, sheet Ivanić-Grad L 33-81. Institut za geološka istraživanja, Zagreb (1969-76), Savezni geološki zavod, Beograd.

Basch, O. 1995: Geological map of the Medvednica Mts. In: Šikić, K. (Ed.): Geology of the Medvednica Mts. Institut za geološka istraživanja, INAIndustrija Nafte Naftaplin Zagreb.

Belak, M., Pamić, J., Kolar-Jurkovšek, T., Pécskay, Z. \& Karan, D. 1995: Alpine low-grade regional metamorphic complex of Mt. Medvednica northwestern Croatia (in Croatian). First Croatian Geological Congress, Proceedings 1, 67-70.

Beyssac, O., Goffé, B., Chopin, C. \& Rouzaud, J.N. 2002: Raman spectra of carbonaceous material in metasediments: a new geothermometer. Journal of Metamorphic Geology 20, 859-871.

Bucher, K. \& Frey, M. 1994: Petrogenesis of metamorphic rocks, 6th edition. Spinger-Verlag, Berlin.

Cathelineau, M. 1988: Cation site occupancy in chlorites and illites as a function of temperature. Clay Minerals 23,471-485.

Crnjaković, M. 1979: Sedimentation of transgressive Senonian in the Southern Mt. Medvednica (in Croatian). Geološki vjesnik 32, 81-95.

Crnjaković, M. 1981: Maastrichtian flysch sediments in the south-west part of Mt. Medvednica (in Croatian). Geološki vjesnik 34, 47-61.

Crnjaković, M. 1987: Sedimentology of Cretaceous and Paleogene clastics of Mt. Medvednica, Ivanščica and Žumberak (in Croatian). Unpublished PhD Thesis, University of Zagreb, 91 pp.

Csontos L. 1999: Structural outline of the Bükk Mts. (N Hungary) (in Hungarian). Földtani Közlöny 129, 611-651.

Csontos, L. 2000: Stratigraphic reevaluation of the Bükk Mts. (N Hungary) (in Hungarian). Földtani Közlöny 130,1-36.

Csontos, L. \& Vörös, A. 2004: Mesozoic plate tectonic reconstruction of the Carpathian region. Palaeogeography, Palaeoclimatology, Palaeoecology $210,1-56$.

Đurđanović, Z. 1973: O paleozoiku i trijasu Medvednice (Zagrebacke gore) i podrucja Dvora na Uni na temelju konodonta. Geoloski vjesnik 25, $29-45$.

Fodor, L., Jelen, B., Márton, E., Skaberne, D., Car, J. \& Vrabec, M. 1998: Miocene-Pliocene tectonic evolution of the Slovenian Periadriatic fault:Implications for Alpine-Carpathian extrusion models. Tectonics 17, 690-709.

Frey, M. 1987: Very low-grade metamorphism of clastic sedimentary rocks. In: Frey, M. (Ed.): Low Temperature Metamorphism. Blackie and Son Ltd., Glasgow, 9-58.

Guidotti, C.V. \& Sassi, F.P. 1986: Classification and Correlation of Metamorphic Facies Series by Means of Muscovite $b_{o}$ data from Low-Grade Metapelites. Neues Jahrbuch für Mineralogie-Abhandlungen 153, 363380.

Haas, J. \& Kovács, S. 2001: The Dinaridic-Alpine connection - as seen from Hungary. Acta Geologica Hungarica 44, 345-362.

Haas, J., Mioč, P., Pamić, J., Tomljenović, B., Árkai, P., Bérczi-Makk, A., Koroknai, B., Kovács, S. \& Felgenhauer, E.R. 2000: Complex structural pattern of the Alpine-Dinaridic-Pannonian triple junction. International Journal of Earth Sciences 89,377-389.

Halamić, J. \& Goričan, Š. 1995: Triassic Radiolarites from the Mts. Kalnik and Medvednica (Northwestern Croatia). Geologica Croatica 48, 129-146.

Halamić, J., Goričan, Š., Slovenec, D. \& Kolar-Jurkovšek, T. 1999: A Middle Jurassic Radiolarite-Clastic Succession from the Medvednica Mt. (NW Croatia). Geologica Croatica 52, 29-57.

Jowett, E.C. 1991: Fitting iron and magnesium into the hydrothermal chlorite geothermometer. Program Abstract Volume GAC/MAC/SEG Joint Annual Meeting, 27-29 May 1991, Toronto, 16, A62.

Judik, K. 2007: Very low-grade metamorphic evolution of Mt. Medvednica (Croatia), comparing with the metamorphism affected Paleozoic and Mesozoic formations in NE Hungary (in Hungarian). Unpublished PhD Thesis, Eötvös Loránd University, Budapest, 197 pp.
Judik, K., Árkai, P., Tibljaš, D., Balen, D., Tomljenović, B., Horváth, P., Dobosi, G. \& Pamić, J. 2004: Diagenesis and low-temperature metamorphism of Mt. Medvednica, Croatia: mineral assemblages and phyllosilicate characteristics. Acta Geologica Hungarica 47, 151-176.

Judik, K., Balogh, K., Tibljaš, D. \& Árkai, P. 2006: New age data on the lowtemperature regional metamorphism of Mt. Medvednica (Croatia). Acta Geologica Hungarica 49, 207-221.

Kisch, H.J. 1987: Correlation between indicators of very low-grade metamorphism. In: Frey, M. (Ed.): Low-temperature metamorphism. Blackie and Son Ltd., Glasgow, 227-301.

Kázmér, M \& Kovács, S. 1985: Permian-Paleogene paleogeography along the eastern part of the Insubric-Periadriatic lineament system: evidence for continental escape of the Bakony-Drauzug Unit. Acta Geologica Hungarica $28,71-84$.

Kovács, S., Szederkényi, T., Haas, J., Buda, Gy., Császár, G. \& Nagymarosy, A. 2000: Tectonostratigraphic terranes in the pre-Neogene basement of the Pannonian area. Acta Geologica Hungarica 43, 225-329.

Kranidiotis, P. \& MacLean, W.H. 1987: Systematics of chlorite alteration at the Phelps Dodge massive sulphide deposit, Matagami, Quebec. Economic Geology 82,1898-1911.

Landis, C.A. 1971: Graphitization of the Dispersed Carbonaceous Material in Metamorphic rocks. Contributions to Mineralogy and Petrology 30, 34-45.

Lugović, B., Šegvić, B. \& Altherr, R. 2006: Petrology, geochemistry and tectonic significance of the orthogreenschists from the SW Zagorje-Transdanubian Zone (Medvednica Mts., Croatia). Ofioliti 31, 39-50.

Merriman, R.J. \& Kemp, S.J. 1996: Clay minerals and sedimentary basin maturity. Mineralogical Society Bulletin 111,7-8.

Merriman, R.J. \& Peacor, D.R. 1999: Very low-grade metapelites: mineralogy, microfabrics and measuring reaction progress. In: Frey, M. \& Robinson, D. (Eds.): Low-grade metamorphism. Blackwell Science Ltd., Oxford, 202226.

Pamić, J. 2002: The Sava-Vardar Zone of the Dinarides and Hellenides versus the Vardar Ocean. Eclogae Geologicae Helvetiae 95, 99-113.

Pamić, J. \& Tomljenović, B. 1998: Basic geologic data from the Croatian part of the Zagorje-Mid-Transdanubian Zone. Acta Geologica Hungarica 41, 389-400.

Pamić, J., Kovács, S., Vozár, J. 2002: The Internal Dinaridic Fragments into the collage of the Southern Pannonian Basin. Geologica Carpathica 53, Special Issue, 9-11.

Pasteris J.D. \& Wopenka, B. 1991: Raman spectra of graphite as indicators of degree of metamorphism. Canadian Mineralogist 29, 1-9.

Rahl, J.M., Anderson, K.M., Brandon, M.T. \& Fassoulas, C. 2005: Raman spectroscopic carbonaceous material thermometry of low-grade metamorphic rocks: Calibration and application to tectonic exhumation in Crete, Greece. Earth and Planetary Science Letters 240, 339-354.

Rantitsch, G., Grogger, W., Teichert, C., Ebner, F., Hofer, C., Mauer, E.M., Schaffer, B. \& Toth, M. 2004: Conversion of carbonaceous material to graphite within the Greywacke Zone of the Eastern Alps. International Journal of Earth Sciences 93, 959-973.

Rantitsch, G., Sachsenhofer, R.F., Hasenhüttl, C., Russegger, B. \& Rainer, T. M. 2005: Thermal evolution of an extensional detachment as constrained by organic metamorphic data and thermal modeling: Graz Paleozoic Nappe Complex (Eastern Alps). Tectonophysics 411, 57-72.

Ripsz-Judik, K. 2008: Comparison of Palaeozoic and Mesozoic very low-grade metamorphic formations in the Medvednica Mts (Croatia) and in North Hungary. Annual Report of the Geological Institute of Hungary 2006, $47-57$.

Schmid S.M., Bernoulli, D., Fügenschuh, B., Matenco, L., Schefer, S., Schuster, R., Tischler, M. \& Ustaszewski, K. 2008: The Alpine-Cartahian-Dinaridic orogenic system: correlation and evolution of tectonic units. Swiss Journal of Geosciences doi: 10.1007/s00015-008-1247-3,1-47.

Šikić, K. (Ed.) 1995: Geology of the Medvednica Mts. (in Croatian). Institut za geološka istraživanja, INA-Industrija Nafte d.d., Naftaplin, Zagreb, $199 \mathrm{pp}$.

Šikić, D., Basch, O. \& Šimunić, A.N. 1977: Geological map SFRJ 1:100.000, sheet Zagreb. Institut za geološka istraživanja, Savezni geološki zavod, Beograd. 
Šikić, D., Basch, O. \& Šimunić, A. 1978: Geological map SFRJ 1:100.000 L 3380. Institut za geološka istraživanja, Beograd.

Slovenec, D. \& Pamić, J 2002: Geology of the Vardar Zone ophiolites of the Medvednica Mountain area located along the Zagreb-Zemplin line (NW Croatia). Geologica Carpathica 53, 53-59.

Sremac, J. \& Mihajlović-Pavlović, M. 1983: Graptoliti Medvednice (Zagrebačke gore). Rad Jugoslavenske Akademije Znanosti i Umjetnosti 404, 65-68.

Sudar, M. \& Kovács, S. 2006: Metamorphosed and ductilely deformed conodonts from Triassic limestones situated beneath ophiolite complexes: Kopaonik Mountain (Serbia) and Bukk Mountains (NE Hungary) - a preliminary comparison. Geologica Carpathica 57, 157-176.

Taylor, G.H., Teichmüller, M., Davis, A., Diessel, C.F.K., Littke, R. \& Robert, P. 1998: Organic Petrology. Gebrüder Borntraeger, Berlin, Stuttgart, 704 pp.

Teichmüller, M. \& Teichmüller, R. 1981: The significance of coalification studies to geology - a review. Bull. Centre Rech. Expl., Prod. ELF-Aquitaine $5,491-534$.

Tomljenović, B. 1995: Stratigraphic and tectonic position of sedimentary complex with mafic igneous rocks on the northwestern slopes of Mt. Medvednica (in Croatian). Unpublished M.Sc. Thesis, University of Zagreb, $68 \mathrm{pp}$.

Tomljenović, B. 2002: Structural characteristics of Medvednica and Samoborsko Gorje Mts (in Croatian). Unpublished PhD Thesis, University of Zagreb, 208 pp.
Tomljenović, B. \& Csontos, L. 2001: Neogene-Quaternary structures in the border zone between Alps, Dinarides and Pannonian Basin (Hrvatsko Zagorje and Karlovac Basins, Croatia). International Journal of Earth Sciences 90, 560-578.

Tomljenović, B., Csontos, L., Márton, E. \& Márton, P. 2008: Tectonic evolution of the northwestern Internal Dinarides as constrained by structures and rotation of Medvednica Mountains, North Croatia. In: Siegesmund, S., Fügenschuh, B. \& Froitzheim, N. (eds): Tectonic Aspects of the AlpineCarpathian-Dinaride System. Geolological Society, London, Special Publications 298, 145-167.

Yui, T.F, Huang, E. \& Xu, J. 1996: Raman spectrum of carbonaceous material: a possible metamorphic grade indicator for low-grade metamorphic rocks. Journal of Metamorphic Geology 14, 115-124.

Vidal, O. \& Parra, T. 2000: Exhumation paths of high pressure metapelites obtained from local equilibria for chlorite-phengite assemblages. Geological Journal 35, 139-161.

Wopenka, B. \& Pasteris, J.D. 1993: Structural characterization of kerogens to granulite-facies graphite: Applicability of Raman microprobe spectroscopy. American Mineralogist, 78, 533-557.

Manuscript received May 13, 2008

Manuscript accepted October 27,2008

Published Online first: December 13, 2008

Editorial handling: Edwin Gnos

616 K. Judik et al. 